\title{
Governança judicial: uma análise dos desafios para a prestação do serviço jurisdicional
}

\author{
Raquel Maria da Costa Silveira \\ Maria do Livramento Miranda Clementino \\ Lindijane de Souza Bento Almeida
}

Universidade Federal do Rio Grande do Norte, Natal - RN, Brasil

As dificuldades enfrentadas pelo cidadão no acesso à justiça são multifacetadas, superando a perspectiva estritamente jurídica. Nesse sentido, o estudo da prestação jurisdicional efetiva deve revestir-se de uma abordagem multidisciplinar. Partindo dos pressupostos que embasam as teorias da agência e dos custos de transação, Akutsu e Guimarães (2015) destacaram a necessidade da realização de estudos que analisem a governança judicial a partir da accountability, da acessibilidade, da independência, dos recursos e estrutura, das práticas de governança, e do ambiente institucional e desempenho. Considerando as categorias elencadas por esse modelo teórico-metodológico, realizou-se estudo que objetivou investigar a governança judicial a partir de pesquisa realizada na Justiça Federal, no Tribunal Regional Eleitoral e no Tribunal Regional do Trabalho do Rio Grande do Norte. Para tanto, foram aplicados questionários com servidores públicos dessas instituições, os quais atribuíram pontuações aos itens que compõem a governança judicial, conforme Akutsu e Guimarães (2015). Ao final, foi possível estudar o nível de governança e analisar os desafios presentes na prestação do serviço jurisdicional. Concluiu-se que os tribunais pesquisados ainda enfrentam desafios diversos no que tange à construção da governança. Os aspectos mais frequentes foram o acesso à justiça e o ambiente institucional.

Palavras-chave: governança judicial, acesso à justiça, serviço jurisdicional 


\section{Gobernanza judicial: análisis de los desafíos para la prestación del servicio jurídico}

Las dificultades que enfrentan los ciudadanos para acceder a la justicia son multifacéticas, superando la perspectiva estrictamente legal. En este sentido, el estudio de la disposición jurisdiccional efectiva debe adoptar un enfoque multidisciplinario. Sobre la base de los supuestos que respaldan las teorías de la agencia y los costos de transacción, Akutsu y Guimarães (2015) destacaron la necesidad de estudios que analicen la gobernanza judicial basada en la rendición de cuentas; en la accesibilidad; en la independencia; en los recursos y la estructura; en las prácticas de gobernanza; en el entorno institucional y en el desempeño. Teniendo en cuenta las categorías enumeradas por este modelo teórico-metodológico, se llevó a cabo un estudio que tenía como objetivo investigar la gobernanza judicial basada en investigaciones realizadas en el Tribunal Federal, el Tribunal Electoral Regional y el Tribunal Laboral Regional de Río Grande del Norte. Para ello, se aplicaron cuestionarios a servidores públicos de estas instituciones, que atribuyeron puntajes a los ítems que conforman la gobernanza judicial según Akutsu y Guimarães (2015). Al final, fue posible estudiar el nivel de gobernanza y analizar los desafíos presentes en la prestación del servicio judicial. Se concluyó que los tribunales encuestados aún enfrentan diferentes desafíos en términos de construcción de gobernabilidad. Los aspectos más frecuentes fueron el acceso a la justicia y el entorno institucional.

Palabras clave: gobernanza judicial, acceso a la justicia, servicio judicial

\section{Judicial governance: an analysis of the challenges for the provision of the legal service}

The difficulties faced by citizens in accessing justice are multifaceted, overcoming the strictly legal perspective. In this sense, the study of effective jurisdictional provision must take a multidisciplinary approach. Based on the assumptions that support the agency's theories and transaction costs, Akutsu and Guimarães (2015) highlighted the need for studies that analyze judicial governance based on accountability; accessibility; independence; resources and structure; governance practices; institutional environment and performance. Considering the categories listed by this theoretical-methodological model, a study was carried out that aimed to investigate judicial governance based on research from the Federal Court, the Regional Electoral Court and the Regional Labor Court of Rio Grande do Norte. To this end, questionnaires were applied with public servants from these institutions, which attributed scores to the items that make up the judicial governance according to Akutsu and Guimarães (2015). In the end, it was possible to study the level of governance and analyze the challenges present in the provision of the judicial service. It was concluded that the surveyed courts still face different challenges in terms of building governance. The most frequent aspects were access to justice and the institutional environment.

Keywords: judicial governance, access to justice, judicial service 


\section{Introdução}

A década de 1990 trouxe consigo uma gama de estudos empíricos na área do Direito. Conforme Geraldo et al. (2010, p. 7), “a pesquisa empírica em direito tem sua origem nas atividades de outras áreas do conhecimento, como a antropologia e a sociologia, logo, um trabalho de certa forma externo ao campo do direito".

Dito isto, considera-se, aqui, a necessidade de que outras áreas e novos conceitos sejam inseridos no debate sobre o Direito e as instituições da Justiça. Isso se explica pelo fato de que as dificuldades enfrentadas pelo cidadão no acesso à Justiça são multifacetadas, devendo superar a perspectiva estritamente jurídica. Nesse sentido, o estudo acerca da ampliação da efetividade da prestação jurisdicional deve revestir-se de uma abordagem multidisciplinar.

Um dos temas a ser explorado é a governança. Aqui, tal conceito será estudado a partir das diretrizes expressas no Decreto Federal $n^{\circ}$ 9.203/2013 e com a perspectiva de Akutsu e Guimarães (2012; 2015).

Conforme os autores, a governança judicial consiste em um conceito multifacetado. Na verdade, a temática é, ainda, pouco explorada, sendo raros os estudos com dados empíricos que analisem as variáveis que se relacionam com o tema. A discussão surgiu da constatação de que as abordagens estritamente jurídicas são insuficientes para estudar questões relacionadas à eficiência da atuação da Justiça. Nesse sentido, torna-se essencial atrelar ao debate a disciplina da governança judicial.

Os autores afirmam que a qualidade da governança judicial pode ser medida pela efetividade das decisões judiciais, pela acessibilidade à Justiça e pela equidade, além da transparência e celeridade com que os serviços judiciais são prestados. Tem-se, portanto, uma perspectiva de múltiplos fatores. Desse modo, o modelo proposto por eles considera aspectos relacionados com a accountability, a acessibilidade, a independência, os recursos e a estrutura, as práticas de governança, o ambiente institucional e o desempenho.

Considerando tais elementos, o presente estudo tomou como base as categorias listadas por Akutsu e Guimarães (2015) para identificar o nível de governança nas instituições pesquisadas. Após a realização de pesquisa bibliográfica, a governança judicial foi investigada no âmbito da Justiça Federal, do Tribunal Regional Eleitoral e do Tribunal Regional do Trabalho do Rio Grande do Norte. Para tanto, foram aplicados 
questionários com servidores públicos de tais instituições, criando uma escala para que fossem atribuídas pontuações aos itens que compõe a governança judicial, conforme Akutsu e Guimarães (2015). Os informantes são servidores desses tribunais, de nível superior e com atuação na área meio (administrativa) ou na área fim (gabinetes e secretárias).

Após a realização dessa etapa, foi possível realizar, em 2018, entrevista semiestruturada com o juiz federal que exercia a função de diretor do foro da Justiça Federal do Rio Grande do Norte, instituição melhor avaliada no presente estudo. Buscou-se, nesse momento, investigar os aspectos diferenciadores da JFRN, os quais podem ter contribuído para o resultado obtido. Os desafios apontados pelos servidores participantes da pesquisa foram apresentados ao diretor do foro, tornando-se possível compreender a sua percepção acerca do resultado da pesquisa.

Ao final, foi possível identificar o nível de governança judicial e apontar os desafios presentes na prestação do serviço jurisdicional em cada instituição. Além disso, percebeu-se quão importante foram as orientações normativas do Conselho Nacional de Justiça para o avanço da governança no Judiciário.

\section{O debate conceitual sobre a governança no setor público}

De acordo com o Tribunal de Contas da União (2014), a importância conferida à governança data das últimas três décadas e guarda relação com o momento em que organizações privadas deixaram de ser geridas diretamente por seus proprietários, passando a ser administradas por terceiros. Diante disso, "Para melhorar o desempenho organizacional, reduzir conflitos, alinhar ações e trazer mais segurança para proprietários, foram realizados estudos e desenvolvidas múltiplas estruturas de governança" (TRIBUNAL DE CONTAS DA UniÃO, 2014, p. 15).

No que tange ao setor público brasileiro, o tema começou a ser discutido a partir da crise fiscal de 1980. Naquele contexto, era necessário tornar o Estado mais eficiente, passando-se a discutir aspectos como a transparência e a prestação de contas na administração pública, objetivando, entre outros aspectos, garantir a entrega de benefícios econômicos, sociais e ambientais para a sociedade; manter os cidadãos informados acerca da tomada de decisões, por meio de dados confiáveis, tempestivos e relevantes e garantir a efetividade dos serviços prestados. 
Conforme Milani e Solinis (2002), o termo remonta à discussão realizada por Ronald Coase em 1937. Porém, foi na década de 1970 que a discussão ganhou destaque, tendo sido reformulada nos anos de 1980 pelo Banco Mundial. Nessa fase, a governança passou a ser encarada como a maneira como o poder é exercido na gestão dos recursos econômicos e sociais.

Mas o que seria governança? Secchi (2009, p. 357) afirma que "a definição de governança não é livre de contestações”. Como afirmam Kissler e Heidemann (2006, p. 480), não há um único conceito, mas sim "uma série de diferentes pontos de partida para uma nova estruturação das relações entre o Estado e suas instituições nos níveis federal, estadual e municipal, por um lado, e as organizações privadas, com e sem fins lucrativos" além dos atores da sociedade civil.

De forma geral, pode-se relacionar o termo governança como sinônimo da capacidade de governo. Conforme Eli Diniz (1997), o termo se refere à eficácia governamental, ou seja, à capacidade de ação do governo. Tal capacidade se revela a partir de três dimensões: a capacidade de comando e de direção do governo; a capacidade de coordenação do governo entre os diferentes interesses e projetos políticos presentes na arena política e a capacidade de implementação, que requer por parte do governante a capacidade de mobilizar os recursos técnicos, institucionais, financeiros e políticos necessários à execução de suas decisões.

No mesmo sentido, para Reis (1994), o termo governança diz respeito à capacidade de governo e se refere ao exercício dinâmico do ato de governar, de apresentar a capacidade de coordenação, de liderança, de implementação e a capacidade de produzir credibilidade como seus elementos constitutivos. Diante dessa discussão, Secchi (2009, p. 358) conceitua governança como "um modelo horizontal de relação entre atores públicos e privados no processo de elaboração de políticas públicas".

De acordo com o TCU (2014, p. 22), governança no setor público consiste em estratégias e mecanismos "de avaliação, direção e monitoramento; e às interações entre estruturas, processos e tradições, as quais determinam como cidadãos e outras partes interessadas são ouvidos, como as decisões são tomadas e como o poder e as responsabilidades são exercidos".

Para essa instituição, a governança no setor público deve ser analisada a partir de quatro perspectivas, a saber: (1) sociedade e Estado, que define as regras e os princípios que orientam a atuação dos agentes públicos e privados regidos pela Constituição; (2) 
entes federativos, esferas de poder e políticas públicas, que se preocupa com as políticas públicas e a relação entre as esferas de poder e a sociedade civil; (3) órgãos e entidades, que garante que cada órgão ou entidade cumpra seu papel legalmente estabelecido; e (4) atividades intraorganizacionais, as quais otimizam os resultados e agregam valor aos órgãos. Aqui, a perspectiva dos órgãos merece destaque. Trata-se da vertente corporativa da governança no setor público, com foco nas organizações, a qual visa à manutenção de propósitos e à otimização dos resultados ofertados por elas aos cidadãos (TCU, 2014).

Em 2017, o Governo Federal brasileiro publicou o Decreto $n^{\circ} 9.203$, o qual dispõe sobre a política de governança da administração pública federal direta, autárquica e fundacional. De acordo com essa norma, a governança pública deve ser compreendida como um conjunto de mecanismos de liderança, estratégia e controle postos em prática para avaliar, direcionar e monitorar a gestão, com vistas à condução de políticas públicas e à prestação de serviços de interesse da sociedade. Tal conceito coaduna-se à perspectiva dos órgãos e entidades apresentada pelo TCU (2014). A referida lei estabelece, ainda, princípios para o desempenho da governança pública no Brasil, sendo eles: capacidade de resposta, integridade, confiabilidade, melhoria regulatória, prestação de contas e responsabilidade, e transparência.

Considerando tais elementos que compõem o conceito de governança no Brasil e, ainda, que o presente estudo tem como foco a análise da governança em órgãos do Poder Judiciário, optou-se, aqui, pela fundamentação da pesquisa nas ideias de Akutsu e Guimarães $(2012 ;$ 2015). Tais autores se dedicaram a entender como o cidadão poderia ter acesso facilitado à Justiça brasileira, elaborando um modelo pautado em dimensões para a construção da governança no Judiciário. Cumpre ressaltar que a base de suas ideias dialoga diretamente com os preceitos esculpidos no Decreto Federal $\mathrm{n}^{\mathrm{o}}$ 9.203/2017, sendo esse mais um aspecto motivador da escolha teórico-metodológica realizada. Diante da utilização dessas ideias, torna-se necessário estudar como os referidos autores compreendem o conceito e como dialogam com a legislação citada.

\section{Compreendendo a governança judicial}

Como afirmam Akutsu e Guimarães (2012), várias são as dificuldades enfrentadas pelo cidadão na busca pela adequada prestação jurisdicional. Tais problemas, por sua vez, podem ser enfrentados com medidas eminentemente ligadas ao 
Direito e a alterações legislativas ou por meio de ações relacionadas com a administração do Judiciário. Por tal aspecto, os autores se dedicam a estudar a governança no Judiciário, buscando contribuir com o exame de soluções para melhorar o sistema judicial brasileiro, identificando dimensões relacionadas ao conceito de governança judicial. Para os autores, a governança é conceituada como uma "ferramenta analítica para compreensão dos fatores que organizam a interação dos atores, a dinâmica dos processos e as regras do jogo" (AKUTSU; GUIMARÃES, 2012, p. 185). Contudo, para compreender o conceito, os autores realizaram uma revisão de literatura coletando 23 estudos sobre o tema, a fim de entender quais eram os aspectos mais relacionados com a governança.

A maior parte dos estudos identificados pelos autores se referia à temática do desempenho do sistema judicial, seguidos por textos que tratavam da independência judicial, accountability, recursos estratégicos do Poder Judiciário, acessibilidade à Justiça e estrutura do Poder Judiciário.

No que tange à independência funcional, por sua vez, os autores evidenciam uma estrita relação com a dimensão da accountability. Esta guarda relação com a existência de um Poder Judiciário independente dos demais poderes. Nesse sentido, "caso a premissa da independência dos juízes e tribunais não se concretize, o desempenho do Judiciário pode ser afetado, uma vez que os juízes teriam dificuldade em proferir sentenças que contrariassem as autoridades dos demais poderes" (AKUTSU;GuimarÃEs, 2012, p. 192).

Dessa forma, deve-se buscar a independência do Judiciário em relação às partes, aos demais interessados no litígio, às pressões populares e aos demais poderes, devendo os juízes se ater à dependência em relação aos princípios e às normas da Constituição.

Os estudos relacionados com a dimensão dos recursos estratégicos objetivam entender como é possível melhorar o desempenho de tribunais com os recursos existentes. Como afirmam os autores, "Indicadores que medem tempestividade, acessibilidade, eficiência e efetividade do sistema judicial podem trazer algumas respostas a essa questão" (AKUTSU; GUIMARÃES, 2012, p. 193).

A acessibilidade se constitui em uma das dimensões estudadas. Ela diz respeito aos mecanismos que podem aproximar os operadores do direito da realidade e dos conflitos vividos pelos cidadãos, permitindo o acesso à Justiça. No que tange à dimensão da estrutura do Poder Judiciário, tem-se a relação com a gama de serviços 
judiciais ofertados, os quais dependem da estrutura e das competências atribuídas ao Poder Judiciário. A intenção dos autores é possibilitar estudos que busquem entender como cada uma dessas dimensões pode influenciar a efetividade da governança do sistema judiciário brasileiro.

Akutsu e Guimarães (2015, p. 939) se basearam na teoria da agência (TA) e da teoria de custos de transação (TCT), utilizadas para explicar contextos diversos e, geralmente, relacionados a empresas privadas. Os autores consideraram que tais pressupostos devem ser transpostos para órgãos do Judiciário, visto que "tanto empresas do setor privado quanto tribunais que integram o Poder Judiciário buscam otimizar a eficiência das transações nas respectivas organizações". De acordo com a teoria da agência, realiza-se a análise acerca da relação entre aquele que delega (o principal) e o agente encarregado de executar o trabalho. Teoriza-se a respeito das hipóteses em que, diante de uma situação de risco, o agente e o principal podem agir de formas distintas em razão das preferências de cada um. Tal comportamento pode se dar em dois casos: o primeiro ocorre quando os objetivos dos atores estão em conflito; já o segundo, consiste na divisão de riscos que se constata quando os atores têm atitudes diferentes em relação ao risco.

Como a discussão acerca da governança judicial se relaciona com o setor público, os autores se utilizam da teoria da agência com foco no primeiro problema, visto que a análise acerca da propensão ao risco do agente e do principal se torna mais relevante em contextos relacionados ao setor privado, onde os atores buscam maximizar o lucro a partir de estratégias diversas em relação aos riscos de cada operação.

No modelo proposto, a teoria dos custos da transação também é útil para o exame da eficiência de práticas de governança. De acordo com seus pressupostos, agentes humanos estão sujeitos à racionalidade limitada e podem estar propensos ao oportunismo. Akutsu e Guimarães (2015) destacam que a análise de instituições judiciais a partir dessa teoria considera que: (a) as práticas de governança influenciam os custos de transação e, em consequência, a eficiência dos serviços do Poder Judiciário; e (b) não existe uma estrutura de governança superior às demais, visto que a eficiência das transações depende da adequação de práticas.

Os autores afirmam que a qualidade da governança judicial pode ser medida pela efetividade das decisões judiciais, pela acessibilidade à Justiça e pela equidade, além da 
transparência e celeridade com que os serviços judiciais são prestados. Tem-se, portanto, uma perspectiva de múltiplos fatores. Como afirmam:

\begin{abstract}
Entende-se, assim, que o conceito de governança é multifacetado e plural, envolve distintas dimensões e está alinhado com práticas de gestão e de controle de organizações, tanto públicas quanto privadas. Buscando delimitar esse conceito especificamente para o Judiciário, (...) adota-se o seguinte conceito de governança judicial: conjunto de políticas, processos, costumes, atitudes, ações, comportamentos e decisões necessários ao exercício da Justiça. Esse conceito parte do pressuposto de que governança judicial se fundamenta em instituições, isto é, em regras, em normas, em padrões de conduta socialmente construídos e legitimados, e manifesta-se em práticas, ações e comportamentos dos distintos atores do Poder Judiciário. (AKUTSU; GUIMARÃES, 2015, p. 942).
\end{abstract}

Trata-se de um conceito, além de tudo, complexo em virtude da multiplicidade de atores que atuam direta ou indiretamente junto ao Poder Judiciário, dentre os quais os autores destacam as partes litigantes, os magistrados, os servidores de tribunais, os advogados, os defensores públicos, os membros do Ministério Público e os membros do Poder Legislativo.

Desse modo, para permitir a análise da governança nesse complexo contexto, os autores subdividiram a governança judicial em 3 níveis: o nível de ambiente institucional, o nível de práticas de governança propriamente dito e o nível individual. O ambiente institucional corresponde às regras do jogo, as quais estão definidas na Constituição e demais leis infraconstitucionais, as quais, se forem modificadas, geram reflexos nas práticas de governança. Entretanto, as organizações são autônomas e possuem regras próprias, as quais devem estar de acordo com o ambiente institucional no qual se inserem. Já o nível individual, por sua vez, se relaciona com a diversidade de agentes que permeiam o Judiciário. São considerados os seguintes aspectos: a accountability; a acessibilidade; a independência; os recursos e a estrutura; as práticas de governança; o ambiente institucional e o desempenho.

A acessibilidade se relaciona com a possibilidade oferecida aos cidadãos de utilizarem os serviços judiciais oferecidos pelo Judiciário, de acessarem o Judiciário, sendo tratados de forma igualitária, independente de sua condição socioeconômica. A accountability, por sua vez, corresponde à responsabilização de quem ocupa um cargo ou função pública em dar publicidade, motivar seus atos e prestar contas. No Judiciário, esse aspecto se relaciona com a motivação dos atos processuais e das sentenças e com a transparência dos atos de gestão dos magistrados e servidores que exercem funções administrativas nos tribunais. 
A independência se relaciona com a capacidade dos magistrados de agirem em conformidade com os princípios e normas do direito, de forma a proteger os direitos dos cidadãos de interesses e pressões que contrariem princípios e normas constitucionais e infraconstitucionais. $\mathrm{O}$ aspecto relacionado aos recursos e à estrutura diz respeito à organização de servidores e magistrados em carreiras; à existência de instalações e equipamentos para o exercício adequado das suas funções; e à existência de sistemas de informação judicial. As práticas de governança, por sua vez, relacionam-se com o conjunto de decisões, contratos e transações em torno de políticas, processos, costumes, atitudes, ações, comportamentos e decisões necessários à solução de conflitos sociais, individuais e coletivos pelo Judiciário.

Já o desempenho guarda proximidade com os resultados alcançados por magistrados e tribunais que indicam o nível de adoção de boas práticas de governança judicial relacionadas aos construtos acessibilidade, accountability, independência e recursos e estrutura e a qualidade dos serviços prestados pelo Poder Judiciário em termos de tempo de julgamento, custo dos processos judiciais e qualidade das sentenças. Por fim, o ambiente institucional corresponde ao conjunto de práticas, princípios, regras e valores que influenciam a atuação e a interação de órgãos do Poder Judiciário com os demais atores sociais.

A partir de tais elementos teóricos, foi realizada pesquisa com servidores do Poder Judiciário no Rio Grande do Norte. Os principais resultados serão apresentados a seguir.

\section{A governança judicial no Rio Grande do Norte}

A presente pesquisa decorreu da realização de um curso ministrado aos servidores do Tribunal Regional do Trabalho da $21^{\text {a }}$ Região, da Justiça Federal do Rio Grande do Norte e do Tribunal Regional Eleitoral do RN. A temática da governança consistiu em um dos principais temas tratados durante a capacitação, debatendo-se, além da conceituação geral, a governança judicial a partir da compreensão de Akutsu e Guimarães (2012; 2015).

O questionário utilizado para a coleta de dados foi elaborado de acordo com as dimensões apresentadas pelos autores citados. Cada servidor preencheu um formulário acerca da prática da governança na instituição em que trabalhava. As instruções presentes no questionário solicitavam que o participante atribuísse uma nota de 1 a 5 
para cada assertiva relacionada com os aspectos que compõem a governança judicial, sendo 1 o valor menos favorável e 5 o mais favorável para cada assertiva. O Quadro 1 que segue apresenta as assertivas apresentadas aos respondentes, as quais serão aqui denominadas como fatores da governança.

Quadro 1- Relação de assertivas presentes no questionário

\begin{tabular}{|c|c|}
\hline $\begin{array}{c}\text { Aspecto da } \\
\text { Governança } \\
\text { Judicial } \\
\end{array}$ & Fatores \\
\hline \multirow{9}{*}{ Acesso à Justiça } & Distância do tribunal até o local de residência do cidadão \\
\hline & Quantidade de Juízes por habitante \\
\hline & Incentivo a práticas de solução extrajudicial de conflitos \\
\hline & Negociação, mediação, conciliação e arbítrio \\
\hline & Oferta de serviços judiciais com rituais simplificados \\
\hline & Renda do cidadão influencia na busca pelo Poder Judiciário \\
\hline & O autor da ação tem garantia de que não será ameaçado pelo réu \\
\hline & Os litigantes têm acesso a bons advogados \\
\hline & A população de baixa renda tem acesso a núcleos de prática jurídica \\
\hline \multirow{8}{*}{ Accountability } & Previsibilidade de decisão dos magistrados \\
\hline & Supervisão da conduta de magistrados \\
\hline & Responsabilização de magistrados e servidores pela gestão de recursos públicos \\
\hline & $\begin{array}{c}\text { Disponibilidade de informação à população sobre processos em andamento e } \\
\text { sobre o funcionamento das varas judiciais }\end{array}$ \\
\hline & Possibilidade de petição e de consulta aos atos processuais por meios eletrônicos \\
\hline & $\begin{array}{l}\text { Coerência na fundamentação dos atos judiciais com o argumento das partes e com } \\
\text { as provas juntadas aos autos }\end{array}$ \\
\hline & Grau de transparência dos atos administrativos \\
\hline & Grau de publicidade sobre a quantidade de processos julgados \\
\hline \multirow{7}{*}{$\begin{array}{l}\text { Independência do } \\
\text { Judiciário }\end{array}$} & Possibilidade de o Executivo impor restrições orçamentárias ao Judiciário \\
\hline & Salários adequados de magistrados e servidores \\
\hline & $\begin{array}{c}\text { Adoção de regras de impessoalidade para nomeação de magistrados de } 2^{\circ} \text { grau e } \\
\text { tribunais superiores }\end{array}$ \\
\hline & Garantia constitucional de vitaliciedade dos mandatários \\
\hline & Repercussão na imprensa dos julgados tidos como mais importantes \\
\hline & $\begin{array}{l}\text { Eficácia da proteção aos magistrados que sofrem ameaças por resultados de } \\
\text { julgamento }\end{array}$ \\
\hline & Critérios de promoção nos tribunais \\
\hline \multirow{10}{*}{$\begin{array}{l}\text { Recursos e } \\
\text { Estrutura }\end{array}$} & Rotatividade de magistrados nas respectivas varas \\
\hline & Confiabilidade, robustez e qualidade de sistemas de informação \\
\hline & Adequação das práticas de incentivo às carreiras de magistrados e servidores \\
\hline & $\begin{array}{l}\text { Possibilidade de intercâmbio de informações entre tribunais via sistema de } \\
\text { informações }\end{array}$ \\
\hline & $\begin{array}{c}\text { Existência de instalações e equipamentos adequados para o atendimento ao } \\
\text { público }\end{array}$ \\
\hline & $\begin{array}{c}\text { Grau de adoção pelos tribunais de gestão orientada por objetivos, metas e } \\
\text { indicadores }\end{array}$ \\
\hline & Conhecimento, experiência e capacitação dos magistrados para julgar processos \\
\hline & Adequação de estruturas funcionais dos tribunais à gestão dos processos judiciais \\
\hline & Conhecimento, experiência e capacitação de servidores e magistrados em gestão \\
\hline & Nível de adoção de padronização de informações em tribunais \\
\hline
\end{tabular}




\begin{tabular}{|c|c|}
\hline $\begin{array}{c}\text { Aspecto da } \\
\text { Governança } \\
\text { Judicial } \\
\end{array}$ & Fatores \\
\hline \multirow{7}{*}{ Desempenho } & Impessoalidade das decisões judiciais \\
\hline & Tempo de julgamento \\
\hline & Custo do processo judicial para as partes litigantes \\
\hline & Estoque de processos não julgados \\
\hline & $\begin{array}{c}\text { Ações repetidas julgadas com base nas orientações decorrentes de repercussão } \\
\text { geral }\end{array}$ \\
\hline & Percentual de ações coletivas relevantes julgadas em relação a ações individuais \\
\hline & Percentual de cumprimento de metas do tribunal \\
\hline \multirow{12}{*}{$\begin{array}{l}\text { Ambiente } \\
\text { Institucional }\end{array}$} & $\begin{array}{l}\text { Possibilidades oferecidas pela legislação processual para interposição de recursos } \\
\text { de caráter protelatório }\end{array}$ \\
\hline & Complexidade do jargão jurídico, da legislação e dos procedimentos judiciais \\
\hline & $\begin{array}{c}\text { Disponibilidade de delegados, defensores públicos e do MP para atender à } \\
\text { população de baixa renda }\end{array}$ \\
\hline & $\begin{array}{c}\text { Adoção de inovações para melhorar a estrutura de funcionamento do Poder } \\
\text { Judiciário }\end{array}$ \\
\hline & Existência de indicadores de acompanhamento quanto à eficiência dos tribunais \\
\hline & Percentual de litígios decorrente do inconformismo com a administração pública \\
\hline & $\begin{array}{l}\text { Grau de discussão dos objetivos estratégicos pela alta administração dos tribunais } \\
\text { com setores representativos da sociedade }\end{array}$ \\
\hline & Frequência de campanhas educativas \\
\hline & $\begin{array}{c}\text { Disponibilidade de informações aos cidadãos acerca de seus direitos perante o } \\
\text { Poder Judiciário }\end{array}$ \\
\hline & Frequência de campanhas sobre justiça itinerante e justiça comunitária \\
\hline & Grau de diversidade entre culturas organizacionais nos órgãos do Poder Judiciário \\
\hline & Grau de interlocução entre os órgãos do Poder Judiciário \\
\hline
\end{tabular}

Fonte: Elaboração pelos autores, 2018.

Além disso, os servidores responderam à seguinte pergunta ao final: "O seu órgão realiza práticas de boa governança?”. Vale destacar que 30 servidores participaram do curso sobre governança; porém, somente oito servidores de cada tribunal responderam ao questionário adequadamente, de forma que as 24 respostas foram utilizadas para a presente análise. A partir da coleta de dados realizada, foi possível, inicialmente, calcular o score de governança de cada uma das instituições pesquisadas conforme a perspectiva dos seus servidores. O cálculo do score foi realizado a partir do somatório de todos os valores atribuídos pelos respondentes. $\mathrm{O}$ somatório das pontuações obtidas permitiu a comparação entre as instituições. Porém, a fim de realizar uma análise do nível de governança de cada tribunal, foi calculada a razão entre o score obtido e a pontuação total máxima a ser obtida caso a instituição obtivesse cinco pontos em todas assertivas presentes no questionário.

O Quadro 2 apresenta os scores e o nível de governança dos tribunais pesquisados. Entre as três instituições, a Justiça Federal do Rio Grande do Norte obteve 
a maior pontuação geral a partir da perspectiva dos seus servidores, seguida pelo TRE/RN e pelo TRT da $21^{a}$ Região.

Quadro 2 - Score geral de governança das instituições pesquisadas

\begin{tabular}{|c|c|c|}
\hline Tribunal & $\begin{array}{c}\text { Score da } \\
\text { Governança }\end{array}$ & $\begin{array}{c}\text { Nível de } \\
\text { Governança }\end{array}$ \\
\hline JFRN & 1608 & 0,7584 \\
\hline TRE/RN & 1511 & 0,7127 \\
\hline TRT21 & 1384 & 0,6528 \\
\hline
\end{tabular}

Fonte: Elaboração pelos autores, 2018.

Após a análise referente aos valores gerais, torna-se necessário entender as pontuações obtidas, compreendendo quais fatores foram mais bem ou pior avaliados pelos participantes de cada instituição. O Gráfico 1 que segue apresenta o valor total obtido por tribunal em cada aspecto que compõe a governança judicial. A sua análise deverá ser realizada conjuntamente com o Quadro 03. Os valores presentes no Quadro 03 representam o somatório das notas (de 1 a 5) atribuídas pelos respondentes em relação a cada aspecto que compõe a governança judicial. Para cada um dos fatores indicados, foi possível calcular a razão entre o valor obtido e a pontuação máxima de cada aspecto, obtendo-se o nível de governança relacionado aos aspectos que compõem a governança judicial.

\section{Gráfico 1 - Pontuação obtida pelos tribunais de acordo com os aspectos que compõem a governança judicial}

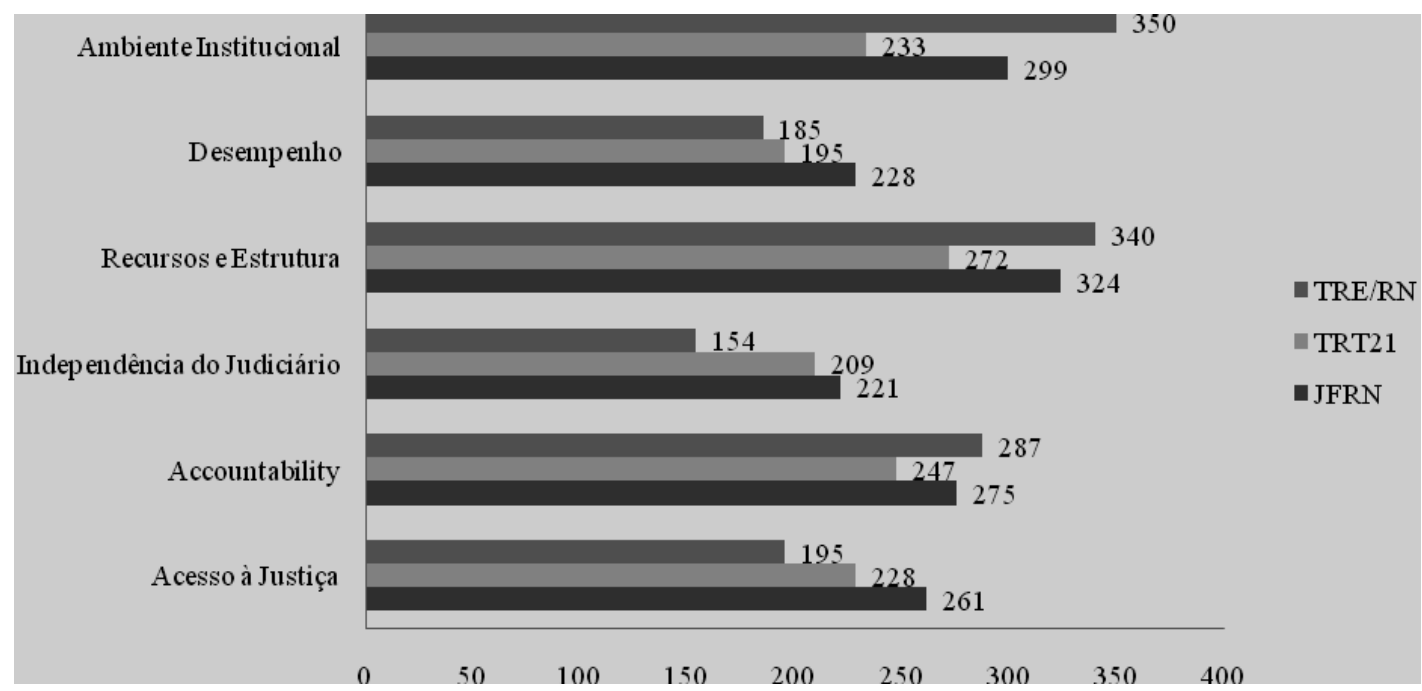

Fonte: Elaboração pelos autores, 2018. 
Quadro 3 - Análise da governança por aspecto pesquisado

\begin{tabular}{|l|r|r|r|r|r|r|}
\hline Aspecto Avaliado & \multicolumn{1}{|c|}{ JFRN } & \multicolumn{1}{c|}{ NG } & TRT21 & \multicolumn{1}{c|}{ NG } & TRE/RN & \multicolumn{1}{c|}{ NG } \\
\hline Acesso à Justiça & 261 & 0,72 & 228 & 0,63 & 195 & 0,54 \\
\hline Accountability & 275 & 0,85 & 247 & 0,77 & 287 & 0,89 \\
\hline Independência do Judiciário & 221 & 0,78 & 209 & 0,74 & 154 & 0,55 \\
\hline Recursos e Estrutura & 324 & 0,81 & 272 & 0,68 & 340 & 0,85 \\
\hline Desempenho & 228 & 0,81 & 195 & 0,69 & 185 & 0,66 \\
\hline Ambiente Institucional & 299 & 0,62 & 233 & 0,48 & 350 & 0,72 \\
\hline
\end{tabular}

Fonte: Elaboração pelos autores, 2018.

Dessa forma, é possível denotar que, com base na percepção dos servidores, de uma forma geral, a Justiça Federal do Rio Grande do Norte possui maior nível de governança em relação aos demais tribunais. Após a análise geral, o estudo realizado em relação a cada aspecto (acesso à Justiça, accountability, independência do Judiciário, recursos e estrutura, desempenho e ambiente institucional) denotou que a Justiça Federal apresenta deficiência (considerada aqui como nível de governança $<0,76$ ) nos aspectos de acesso à Justiça e ambiente institucional.

No acesso à Justiça, as dificuldades (fatores que alcançaram pontuação < 0,76) se relacionam com a localização do foro em relação às áreas residenciais da cidade; à quantidade de juízes por habitante; à inexistência de garantia ao autor de que não será ameaçado pelo réu; ao acesso das partes a bons advogados e a núcleos de prática jurídica.

No que tange ao ambiente institucional, os servidores consideram que a possibilidade de interposição de recursos protelatórios e o jargão jurídico utilizado ainda representam travas ao exercício da Justiça, além da existência de litígios decorrentes do inconformismo com ações decorrentes da própria administração pública. Os servidores consideram que a discussão dos objetivos estratégicos pela alta administração dos tribunais com setores representativos da sociedade ainda não é ideal, bem como é necessário ampliar a disponibilidade de informações aos cidadãos acerca de seus direitos perante o Poder Judiciário, o que poderá ser realizado por meio de campanhas sobre justiça itinerante, justiça comunitária e estratégias participativas. Soma-se a isso, a visão de que é necessária uma maior interlocução entre a Justiça Federal e outros órgãos do Poder Judiciário. 
A análise das principais dificuldades encontradas no Tribunal Regional Eleitoral, por sua vez, expressa como principais dificuldades o acesso à Justiça, a independência do Judiciário, o Desempenho e o ambiente institucional.

As deficiências ressaltadas pelos servidores do TRE/RN no que tange ao acesso à Justiça se relacionam, de forma geral, com a necessidade de ampliação de práticas de solução extrajudicial de conflitos; com a ausência de garantia de inexistência de ameaça do autor pelo réu e com a influência da renda no acesso ao Judiciário, principalmente no que diz respeito à contratação de advogados ou apoio de núcleos de prática jurídica.

A independência do Judiciário também se configurou como dificuldade na percepção dos servidores do Tribunal Regional Eleitoral, visto que esses avaliaram a possibilidade de imposição de restrições orçamentárias pelo Poder Executivo, a adoção de regras de impessoalidade para nomeação de magistrados de $2^{\circ}$ grau, a garantia de vitaliciedade, a proteção aos magistrados contra ameaças e os critérios de nomeação dos tribunais como fatores a ser aprimorados no TRE/RN.

Conforme julgaram os servidores, o aspecto relativo ao desempenho carece de atenção pelo Tribunal, principalmente no que tange ao cumprimento das metas e à celeridade do julgamento de ações com base em orientações provenientes de repercussão geral. Para os referidos participantes, a legislação ainda possibilita a interposição de recursos protelatórios e o jargão jurídico ainda representa um entrave à adequada prestação jurisdicional. A população, por sua vez, ainda não possui acesso amplo a delegados, defensores públicos e membros do Ministério Público, sendo importante a ampliação das campanhas sobre justiça itinerante e comunitária. Além disso, foram atribuídas pontuações abaixo do esperado no que tange aos fatores que traduzem a necessidade de interlocução entre os órgãos do Judiciário.

O TRT da $21^{\text {a }}$ Região, por sua vez, também apresentou dificuldades no que tange ao acesso à Justiça, à independência do Judiciário, aos recursos e estrutura, ao desempenho e ao ambiente institucional. No caso do TRT/21, assim como na Justiça Federal do RN, a distância do tribunal das áreas residenciais da cidade foi apontada como fator que dificulta o acesso. Deve-se destacar que os dois tribunais se localizam na mesma região, onde também funcionam a Polícia Federal e a sede do Tribunal de Justiça do Estado do Rio Grande do Norte.

$\mathrm{O}$ acesso à Justiça foi, igualmente, apontado como dificultoso em função da baixa quantidade de Juízes do Trabalho, da qual decorre a necessidade de incentivo a 
práticas de solução extrajudicial de conflitos. Para os respondentes, na Justiça Trabalhista, o reclamante ainda não possui garantias de que não será ameaçado pelo reclamado, motivo pelo qual, por vezes, poderá optar por não pleitear seu direito. Em outros casos, as partes não dispõem de acesso a bons advogados ou a núcleos de prática jurídica para patrocinar suas causas. Tais fatores, que também se repetiram nos demais tribunais estudados, confirmam os resultados encontrados por Akutsu e Guimarães (2015, p. 949), segundo os quais "muitas vezes, a limitação de acesso ao Poder Judiciário é imposta por atores externos ao referido Poder”.

A independência do Judiciário foi o segundo aspecto desfavorável indicado pelos participantes do TRT/21. Para eles, ainda se faz necessária a adoção de regras mais claras no que tange à impessoalidade para a nomeação de magistrados para o $2^{\circ}$ grau e tribunais superiores. Além disso, na esfera trabalhista, ainda parecem ser comuns as ameaças sofridas por magistrados em função dos julgamentos proferidos.

Entre os três tribunais pesquisados, o aspecto relativo a recursos e estrutura somente foi destacado pelos servidores do TRT/21 como obstáculo à governança, sendo necessária maior adequação dos inventivos às carreiras de magistrados e servidores, atenção à possibilidade de intercâmbio de informações entre tribunais, adoção de uma gestão orientada por objetivos, metas e indicadores. Nesse aspecto, destacou-se, ainda, a necessidade de adequação das estruturas funcionais dos tribunais à gestão dos processos, o investimento em capacitação de magistrados e servidores em gestão e a padronização de informações entre os tribunais.

No que tange aos recursos e estrutura, vale ressaltar que a pesquisa aqui realizada, de um lado, confirmou os fatores adicionais apontados por Akutsu e Guimarães (2015, p. 951), especificamente em relação ao contexto do TRT/21; porém, de outro, evidenciou que "ao contrário das comarcas em pequenos municípios, os recursos e a estrutura disponíveis para os tribunais superiores, embora possam ser relevantes, não se constituem, nesses órgãos, uma limitação para boas práticas de governança”.

Para os respondentes, o desempenho da instituição também poderá ser aprimorado, devendo-se atentar para o tempo de julgamento, que se reflete no estoque de processos pendentes de julgamento e no custo do processo judicial para as partes litigantes. Nesse sentido, destacou um dos servidores da instituição:

(...) apesar dos papéis desempenhados pela Corregedoria/Ouvidoria percebemos uma baixa responsabilização de magistrados e servidores pela 
gestão de recursos públicos, principalmente no que diz respeito a atraso de sentenças, reiterados aumentos no volume de estoque de processos não resolvidos e em decisões administrativas que contrariam o princípio do interesse público (SERVIDOR DO TRT/21, 2017).

Por fim, o ambiente institucional também foi foco dos respondentes, em função da possibilidade de interposição de recursos protelatórios, da complexidade do jargão jurídico empregado no ambiente judicial e da baixa disponibilidade de delegados, defensores públicos e membros do Ministério Público acessíveis à população de baixa renda. Assim como indicado nos casos anteriores, também foi apontado o alto percentual de litígios decorrente do inconformismo dos cidadãos com ações da própria administração pública e a necessidade de ampliação do contato entre o Judiciário e a sociedade por meio de campanhas educativas e da disponibilização de informações em relação aos direitos, sendo, igualmente, essencial a ampliação da interlocução entre os órgãos do Poder Judiciário.

Após a análise das particularidades que representam obstáculos à instituição da governança judicial nos tribunais pesquisados, foi possível concluir que, entre os aspectos listados por Akutsu e Guimarães (2015), o acesso à Justiça e o ambiente institucional foram considerados como deficiências nos três casos estudados. O primeiro avalia fatores que podem "facilitar ou dificultar os servidores e magistrados a alcançarem os resultados contratados (metas fixadas pelos tribunais)", já o segundo destaca fatores "que podem influenciar a interação dos agentes (servidores do Judiciário e magistrados) com as partes litigantes, com outros órgãos públicos e com os demais atores do Poder Judiciário" (AKUTSU; GUIMARÃES, 2015, p. 954). Já a independência do Judiciário e o desempenho foram ressaltados apenas no TRE/RN e no TRT/21. Neste somente, por sua vez, foram encontradas dificuldades relativas aos recursos e estrutura.

Após estudar as dificuldades na construção da governança judicial nas três instituições, foi possível identificar a JFRN como organização mais bem avaliada a partir da perspectiva dos servidores. Nesse sentido, a fim de investigar as motivações e aspectos diferenciais entre essa e as demais instituições, foi realizada uma entrevista semiestruturada com o juiz federal que, em 2018, ocupava a função de diretor do foro da JFRN. O entrevistado foi, inicialmente, informado acerca dos resultados obtidos com a pesquisa, questionando-se, em seguida, acerca da sua percepção sobre os aspectos e fatores listados como dificuldades e sobre os possíveis elementos que poderão ter conduzido a JFRN a melhores resultados. 
De acordo com o entrevistado, esse resultado pode ser atribuído a alguns fatores principais: “(...) incentivo à inovação e a coragem de romper com certos entraves burocráticos". Principalmente a partir da nova gestão, iniciada em 2015, foram citadas ações relacionadas à área administrativa da JFRN que podem ter, igualmente, gerado reflexos na construção da governança, a exemplo da criação de um escritório de projetos, a fim de planejar as ações e iniciativas de forma estratégica. Além disso, foram propagadas máximas que passaram a reger o trabalho realizado na instituição, as quais se relacionam com a cultura organizacional estabelecida e a dinâmica de trabalho do foro. De acordo com o entrevistado:

(...) tem três frases aqui que se tornaram muito impactantes e que mudaram um pouco a forma como a área administrativa encarava a instituição. A primeira delas é: "você é proibido de dizer não. Você é proibido de dizer não, a partir de hoje dizer não vai ter que lhe dar trabalho. (...) Então aquele reflexo da burocracia que tornava mais cômodo dizer não, foi modificado (...). A segunda frase para a área administrativa, que é muito chocante para quem ouve pela primeira vez é: "a JFRN é um shopping. Se você estiver olhando para um lado e para o outro e estiver vendo que algo na JFRN está diferente do principal shopping da cidade, pode ir atrás porque alguma providência precisa ser tomada". E aí isso... lógico que ninguém vai comparar a estrutura de um shopping, mas isso fez com que eles... que a criatividade se despertasse, porque claro, ele não vai ter os insumos e a facilidade para resolver o problema que se tem no shopping, mas ele vai usando a criatividade e encontrar uma solução que seja esteticamente compatível. (...) E isso teve um reflexo muito positivo, porque os próprios servidores - aí vem a terceira expressão - criaram um conceito aqui chamado de hashtag padrão JFRN.

Os aspectos destacados pelo entrevistado denotam que os resultados alcançados pela JFRN podem ser reflexo da atenção conferida, historicamente, pelos diretores de foro à área-fim da JFRN. Entretanto, também podem ser atribuídos à criação de uma nova lógica interna de trabalho, denominada como \#padrãoJFRN, a qual se caracteriza pela excelência do tratamento conferido ao público e à necessidade de ofertar boas condições de infraestrutura para a prestação jurisdicional. Qualquer ação em desconformidade com esse padrão, segundo o diretor, geraria uma espécie de reprimenda moral ao servidor. Conforme relatou, essa cultura foi propagada por meio de reuniões administrativas e representou meios para a promoção do empoderamento do servidor: "E o que eu acho mais engraçado, é que os servidores eles sorriam, porque é como se estivessem esperando esse momento do empoderamento".

Em seguida, o entrevistado foi estimulado a analisar as dificuldades apontadas pelos servidores da JFRN para a construção da governança. Para ele, algumas 
dificuldades presentes no rol de desafios se relacionam ao sistema jurídico brasileiro, não sendo uma exclusividade da JFRN.

Nesse sentido, quanto ao aspecto de acesso à Justiça, todos os desafios foram considerados pelo entrevistado como desafios gerais da Justiça brasileira. Para ele, a indicação da distância da sede da instituição em relação à residência do cidadão é, de fato, uma dificuldade, tanto em relação à sede, como, principalmente, se for considerada a existência de apenas cinco tribunais federais no país. Como afirmou:

(...) quando o nosso servidor está lendo essa pergunta e está interpretando o tribunal, ele está pensando no cidadão de Parelhas e no desembargador em Recife, então ele já vai dizer que está distante. (...) Então você imagina que um cidadão lá perto da Venezuela o tribunal dele está em Brasília, então é super distante.

Tal fator, para ele, contribui para a geração de dificuldades na prestação jurisdicional. Por outro lado, outros fatores foram indicados pelo entrevistado como estratégias pensadas pelo sistema jurídico brasileiro para facilitar o acesso à Justiça, mas que, contudo, acabam por criar desafios concretos às instituições. Nesse sentido, destacou-se que o estabelecimento desses mecanismos foram potencializadores da demanda pela Justiça Federal de forma geral: “O sistema jurídico é muito barato (...). As custas processuais no Brasil são muito baixas, (...) os juizados especiais federais, você nem custas tem. E aí primeira instância nem condenação em honorários você tem, é rigorosamente gratuito".

Ao mesmo tempo, a previsão de conceitos jurídicos indeterminados na Constituição Federal e em legislações infraconstitucionais gerou o aumento da demanda pelo Judiciário, fazendo crescer o número de ações e tornando cada vez mais necessário ampliar o número de profissionais para julgar processos relativos à atuação ou omissão do Estado na concretização das políticas públicas:

(...) Quem pensa coletivamente o país é a União e, portanto, é a justiça federal que vai ser o eco daquilo que não dá certo nessas políticas públicas. Porque como a gente tem as políticas públicas no Brasil muito judicializadas, ou seja, política pública no Brasil é um elemento jurídico, tudo vem para cá. (...) conceitualmente nós deveríamos ser uma justiça um pouco mais residual, mas por conta desse déficit de cidadania nós somos muito cobrados.

Tal elemento, confirmado pelo entrevistado como dificuldade enfrentada pelo sistema jurídico brasileiro de forma geral, se relaciona à existência de litígios decorrentes do inconformismo com ações da administração pública, o qual também foi apontado como dificuldade pelos servidores no aspecto relativo ao ambiente institucional. Nesse sentido, o entrevistado afirmou não considerar baixo o número de 
juízes existente, sendo problemático, porém, o aumento da demanda pelo Judiciário de forma geral e da Justiça Federal de forma específica:

Você sabia que eu já acho muito [referindo-se ao número de juízes]? O problema é que eu acho que a demanda não deveria ser tão alta, eu acho irracional a demanda. Acho, sabe? Por exemplo, aqui [referindo-se a sua vara] eu tenho 30 mil processos em cobrança, não é normal.

A garantia do autor de que não será ameaçado pelo réu foi outro fator apontado como um desafio a ser enfrentado por todo o sistema jurídico brasileiro: "Teoricamente isso é algo que precisa vir de uma política pública que é do Ministério da Justiça, que é proteção à testemunha, é você ter um efetivo na Polícia Federal para oferecer proteção ao réu”. Igualmente, o acesso a bons advogados e a núcleos de prática jurídica foram confirmados pelo entrevistado como dificuldades, porém, foram identificados como desafios que ultrapassam a capacidade de atuação da JFRN: "o grande problema é o excesso de advogados no Brasil (...) você imaginar, por exemplo, que o Rio Grande do Norte tem 3 milhões e pouco de habitantes, 20 mil advogados, é muito advogado. É difícil num universo de 20 mil pessoas você ter 20 mil pessoas super qualificadas".

No que tange aos oito fatores listados como dificuldades pelos servidores, três deles foram apontados pelo entrevistado como desafios da Justiça brasileira, sendo eles: possibilidades oferecidas pela legislação processual para interposição de recursos de caráter protelatório; complexidade do jargão jurídico, da legislação e dos procedimentos judiciais; existência de litígios decorrentes do inconformismo com ações da administração pública.

Por outro lado, o grau de discussão dos objetivos estratégicos pela alta administração dos tribunais com setores representativos da sociedade foi reconhecido como um desafio interno. Para exemplificar a sua opinião, o entrevistado citou o exemplo da relação interna entre os próprios juízes e servidores, como balizador para a compreensão do fator em discussão:

(...) Nós somos mais hierarquizados do que a justiça do trabalho e sobretudo a justiça eleitoral. Porque como a justiça eleitoral não tem magistratura própria, os servidores são muito fortes lá dentro. Aqui é uma coisa meio histórica, e aqui no Rio Grande do Norte é mais do que em outros locais. Eu reconheço que é um problema institucional nosso, mas que eu acho que tem melhorado.

De forma relacionada a essa melhoria relatada por ele, foi citado, também, o aumento gradativo de informações prestadas aos cidadãos, um esforço realizado nos últimos anos. Como afirmou: "É porque eu acho que... - por incrível que pareça, é meio 
ridículo, mas isso é do ano passado para cá - (...) nos últimos dois anos a gente vem fortalecendo muito essa área com a central de atendimento lá embaixo”. Tal elemento se relaciona com o princípio da capacidade de resposta presente no Decreto Federal $\mathrm{n}^{\circ}$ 9.203/2017.

A despeito desse investimento em ações voltadas a prestar informações ao cidadão, o entrevistado destacou que a dificuldade apontada no que tange à frequência de campanhas sobre justiça itinerante e justiça comunitária é proposital, visto que a realização dessas ações poderia incentivar o aumento da demanda pelo Judiciário:

A gente não faz isso, a gente fazia no passado, por quê? Porque a gente viu que isso atraia muita litigiosidade. E como a gente já tem litigiosidade mais elevada, a gente começou fazendo, depois a gente viu que estava se tornando pernicioso. (...) Porque como a gente lida com políticas públicas, a gente não lida com problemas individualizados.

Também foram confirmados os aspectos relativos ao grau de diversidade entre culturas organizacionais nos órgãos do Poder Judiciário e ao baixo grau de interlocução entre os seus órgãos. Para o entrevistado, contudo, embora exista a diversidade de culturas organizacionais, este fator não deve ser visto como problema. Por outro lado, o baixo grau de interlocução entre os órgãos do Poder Judiciário vem sendo gradativamente superado no Rio Grande do Norte:

\begin{abstract}
Aí eu acho que cada instituição é uma instituição, e ela deve criar culturas organizacionais considerando suas próprias particularidades. E o grau de interlocução entre os órgãos do Poder Judiciário, aí... (...) o presidente da FIERN quando nos chamou lá para assinar o convênio, ele ficou muito impressiona porque foi o que eu disse na hora, eu disse, "doutor (...), o que é mais impressionante é que assim, a primeira vez em que esses três tribunais estão sentados na mesma mesa”. Aí ele ficou super feliz. E é um absurdo, mas é o que acontecia.
\end{abstract}

A partir da entrevista realizada com o diretor do foro, é possível ressaltar que, entre os fatores apontados como desafios na JFRN, predominam dificuldades criadas pelo sistema brasileiro.

Contudo, uma ponderação dever ser feita no que diz respeito à cultura organizacional. A despeito de o entrevistado não considerar relevante a existência de uma diversidade de culturas organizacionais entre os órgãos do Judiciário, deve-se destacar que a criação de uma cultura organizacional voltada ao resultado e ao bom atendimento ao cidadão (que indicam a existência de servidores e magistrados focados nos mesmos objetivos) foi justamente um dos elementos citados durante a entrevista como motivador do resultado alcançado pela JFRN na presente pesquisa. A existência 
de valores e dinâmicas de trabalho estabelecidas nessa instituição (a exemplo do \#padrão JFRN) demonstrou-se um diferenciador em relação ao TRT21 e o TRE/RN.

Além de destacar as deficiências por tribunal, o estudo realizado tornou possível destacar que alguns aspectos não foram apontados como dificuldades na construção da governança judicial em nenhum dos tribunais analisados. O Quadro 4 que segue apresenta a listagem de tais fatores:

\section{Quadro 4 - Fatores avaliados como muito favoráveis por tribunal estudado}

\begin{tabular}{|c|c|c|c|c|}
\hline $\begin{array}{c}\text { Aspecto da } \\
\text { Governança } \\
\text { Judicial } \\
\end{array}$ & Fatores & $\begin{array}{l}\text { JF/ } \\
\text { RN }\end{array}$ & $\begin{array}{l}\text { TRE/ } \\
\text { RN }\end{array}$ & $\begin{array}{l}\text { TRT } \\
/ 21\end{array}$ \\
\hline \multirow{6}{*}{ Acesso à Justiça } & Distância do tribunal até o local de residência do cidadão & & $\mathrm{x}$ & \\
\hline & Quantidade de Juízes por habitante & & $\mathrm{x}$ & \\
\hline & Incentivo a práticas de solução extrajudicial de conflitos & $\mathrm{x}$ & & \\
\hline & Negociação, mediação, conciliação e arbítrio & $\mathrm{x}$ & & \\
\hline & Oferta de serviços judiciais com rituais simplificados & $\mathrm{x}$ & $\mathrm{x}$ & $\mathrm{X}$ \\
\hline & Renda do cidadão influencia na busca pelo Poder Judiciário & $\mathrm{x}$ & & $\mathrm{x}$ \\
\hline \multirow{8}{*}{ Accountability } & Previsibilidade de decisão dos magistrados & $\mathrm{x}$ & $\mathrm{x}$ & $\mathrm{x}$ \\
\hline & Supervisão da conduta de magistrados & $\mathrm{x}$ & $\mathrm{x}$ & $\mathrm{x}$ \\
\hline & $\begin{array}{l}\text { Responsabilização de magistrados e servidores pela gestão } \\
\text { de recursos públicos }\end{array}$ & $\mathrm{x}$ & $\mathrm{x}$ & $\mathrm{x}$ \\
\hline & $\begin{array}{l}\text { Disponibilidade de informação à população sobre processos } \\
\text { em andamento e sobre o funcionamento das varas judiciais }\end{array}$ & $\mathrm{x}$ & $\mathrm{x}$ & $\mathrm{x}$ \\
\hline & $\begin{array}{l}\text { Possibilidade de petição e de consulta aos atos processuais } \\
\text { por meios eletrônicos }\end{array}$ & $\mathrm{x}$ & $\mathrm{x}$ & $\mathrm{x}$ \\
\hline & $\begin{array}{l}\text { Coerência na fundamentação dos atos judiciais com o } \\
\text { argumento das partes e com as provas juntadas aos autos }\end{array}$ & $\mathrm{x}$ & $\mathrm{x}$ & $\mathrm{x}$ \\
\hline & Grau de transparência dos atos administrativos & $\mathrm{x}$ & $\mathrm{x}$ & $\mathrm{x}$ \\
\hline & $\begin{array}{l}\text { Grau de publicidade dos resultados alcançados relativos à } \\
\text { quantidade de processos julgados. }\end{array}$ & $\mathrm{x}$ & $\mathrm{x}$ & $\mathrm{x}$ \\
\hline \multirow{7}{*}{$\begin{array}{l}\text { Independência } \\
\text { do Judiciário }\end{array}$} & $\begin{array}{l}\text { Possibilidade de o Executivo impor restrições orçamentárias } \\
\text { ao Judiciário }\end{array}$ & $\mathrm{x}$ & & $\mathrm{x}$ \\
\hline & Salários adequados de magistrados e servidores & $\mathrm{x}$ & $\mathrm{x}$ & $\mathrm{x}$ \\
\hline & $\begin{array}{c}\text { Adoção de regras de impessoalidade para nomeação de } \\
\text { magistrados de } 2^{\circ} \text { grau e tribunais superiores }\end{array}$ & $\mathrm{x}$ & & \\
\hline & Garantia constitucional de vitaliciedade dos mandatários & $\mathrm{x}$ & & $\mathrm{x}$ \\
\hline & $\begin{array}{c}\text { Repercussão na imprensa dos julgados tidos como mais } \\
\text { importantes }\end{array}$ & $\mathrm{x}$ & $\mathrm{x}$ & $\mathrm{x}$ \\
\hline & $\begin{array}{c}\text { Eficácia da proteção aos magistrados que sofrem ameaças } \\
\text { por resultados de julgamento }\end{array}$ & $\mathrm{x}$ & & \\
\hline & Critérios de promoção nos tribunais & $\mathrm{x}$ & & $\mathrm{x}$ \\
\hline \multirow{5}{*}{$\begin{array}{l}\text { Recursos e } \\
\text { Estrutura }\end{array}$} & Rotatividade de magistrados nas respectivas varas judicias & $\mathrm{x}$ & $\mathrm{x}$ & $\mathrm{x}$ \\
\hline & $\begin{array}{l}\text { Confiabilidade, robustez e qualidade de sistemas de } \\
\text { informação judicial }\end{array}$ & $\mathrm{x}$ & $\mathrm{x}$ & $\mathrm{X}$ \\
\hline & $\begin{array}{l}\text { Adequação das práticas de incentivo às carreiras de } \\
\text { magistrados e servidores }\end{array}$ & $\mathrm{X}$ & $\mathrm{X}$ & \\
\hline & $\begin{array}{c}\text { Possibilidade de intercâmbio de informações entre tribunais } \\
\text { via sistema de informações }\end{array}$ & $\mathrm{x}$ & $\mathrm{X}$ & \\
\hline & $\begin{array}{c}\text { Existência de instalações e equipamentos adequados para o } \\
\text { atendimento ao público }\end{array}$ & $\mathrm{x}$ & $\mathrm{x}$ & $\mathrm{X}$ \\
\hline
\end{tabular}




\begin{tabular}{|c|c|c|c|c|}
\hline $\begin{array}{c}\text { Aspecto da } \\
\text { Governança } \\
\text { Judicial } \\
\end{array}$ & Fatores & $\begin{array}{l}\text { JF/ } \\
\text { RN }\end{array}$ & $\begin{array}{l}\text { TRE/ } \\
\text { RN }\end{array}$ & $\begin{array}{l}\text { TRT } \\
/ 21\end{array}$ \\
\hline & $\begin{array}{c}\text { Grau de adoção pelos tribunais de gestão orientada por } \\
\text { objetivos, metas e indicadores }\end{array}$ & $\mathrm{x}$ & $\mathrm{x}$ & \\
\hline & $\begin{array}{l}\text { Conhecimento, experiência e capacitação dos magistrados } \\
\text { para julgar processos }\end{array}$ & $\mathrm{x}$ & $\mathrm{x}$ & $\mathrm{X}$ \\
\hline & $\begin{array}{l}\text { Adequação de estruturas funcionais dos tribunais à gestão } \\
\text { dos processos judiciais }\end{array}$ & $\mathrm{x}$ & $\mathrm{x}$ & \\
\hline & $\begin{array}{c}\text { Conhecimento, experiência e capacitação de servidores e } \\
\text { magistrados em gestão }\end{array}$ & $\mathrm{x}$ & $\mathrm{x}$ & \\
\hline & $\begin{array}{c}\text { Nível de adoção de padronização de informações em } \\
\text { tribunais }\end{array}$ & $\mathrm{x}$ & $\mathrm{x}$ & \\
\hline \multirow{7}{*}{ Desempenho } & Impessoalidade das decisões judiciais & $\mathrm{x}$ & $\mathrm{x}$ & $\mathrm{x}$ \\
\hline & Tempo de julgamento & $\mathrm{x}$ & $\mathrm{x}$ & \\
\hline & Custo do processo judicial para as partes litigantes & $\mathrm{x}$ & $\mathrm{x}$ & \\
\hline & Estoque de processos não julgados & $\mathrm{x}$ & $\mathrm{x}$ & \\
\hline & $\begin{array}{c}\text { Ações repetidas julgadas com base nas orientações } \\
\text { decorrentes de repercussão geral }\end{array}$ & $\mathrm{x}$ & & $\mathrm{x}$ \\
\hline & $\begin{array}{l}\text { Percentual de ações coletivas relevantes julgadas em relação } \\
\text { a ações individuais }\end{array}$ & $\mathrm{x}$ & & \\
\hline & Percentual de cumprimento de metas do tribunal & $\mathrm{x}$ & & $\mathrm{x}$ \\
\hline \multirow{6}{*}{$\begin{array}{l}\text { Ambiente } \\
\text { Institucional }\end{array}$} & $\begin{array}{l}\text { Disponibilidade de delegados, defensores públicos e do MP } \\
\text { para atender à população de baixa renda }\end{array}$ & $\mathrm{x}$ & & \\
\hline & $\begin{array}{l}\text { Percentual de litígios decorrente do inconformismo com } \\
\text { ações da administração pública }\end{array}$ & $\mathrm{x}$ & $\mathrm{X}$ & \\
\hline & $\begin{array}{c}\text { Adoção de inovações para melhorar a estrutura de } \\
\text { funcionamento do Poder Judiciário }\end{array}$ & $\mathrm{x}$ & $\mathrm{X}$ & $\mathrm{x}$ \\
\hline & $\begin{array}{l}\text { Existência de indicadores de acompanhamento quanto à } \\
\text { eficiência dos tribunais }\end{array}$ & $\mathrm{x}$ & $\mathrm{X}$ & $\mathrm{X}$ \\
\hline & Frequência de campanhas educativas & $\mathrm{x}$ & $\mathrm{x}$ & \\
\hline & $\begin{array}{c}\text { Disponibilidade de informações aos cidadãos acerca de seus } \\
\text { direitos perante o Poder Judiciário }\end{array}$ & & $\mathrm{X}$ & \\
\hline
\end{tabular}

Fonte: Elaboração pelos autores, 2018.

O Quadro 4 acima denota que, no aspecto referente ao acesso à Justiça, a oferta de serviços judiciais com rituais simplificados foi avaliada positivamente nos três tribunais. No mesmo sentido, no que tange à independência do Judiciário, os salários adequados de magistrados e servidores e a repercussão na imprensa dos julgados tidos como mais importantes foram positivamente avaliados em todos os casos. No aspecto de recursos e estrutura, a rotatividade de magistrados nas respectivas varas judicias, a confiabilidade, robustez e qualidade de sistemas de informação judicial, a existência de instalações e equipamentos adequados para o atendimento ao público, o conhecimento, experiência e capacitação dos magistrados para julgar processos foram destacados positivamente na pesquisa. 
No aspecto do desempenho, somente a impessoalidade das decisões judiciais foi positivamente avaliada nos três tribunais. No ambiente institucional, por sua vez, dois fatores foram positivamente avaliados: a adoção de inovações para melhorar a estrutura de funcionamento do Poder Judiciário e a existência de indicadores de acompanhamento quanto à eficiência dos tribunais, que se relaciona com o Decreto Federal n n 9.203/2017, o qual estabelece como diretriz: monitorar o desempenho e avaliar a concepção, a implementação e os resultados das políticas e das ações prioritárias.

Vale ressaltar que todos os fatores referentes à accountability foram positivamente avaliados nos três tribunais, aproximando o contexto estudado dos resultados apontados por Akutsu e Guimarães (2015, p. 949), os quais afirmaram, após a realização de suas entrevistas que "apesar do "estigma de ser uma caixa preta", o Poder Judiciário é um dos órgãos que mais presta conta de suas ações". Acerca do aspecto accountability, os servidores das instituições pesquisadas destacaram:

\section{Quadro 5 - Percepção de servidores sobre a accoutability nos tribunais pesquisados}

\begin{tabular}{|c|c|}
\hline Tribunal & Percepção do Servidor \\
\hline TRE/RN & $\begin{array}{l}\text { Quanto à accountability, trata-se de um órgão com boa publicidade de decisões, } \\
\text { principalmente as mais importantes, e cujo acompanhamento da população é feito de } \\
\text { perto (...). Tem uma boa procura, neste quesito, nas épocas de campanha eleitoral. Ao } \\
\text { mesmo tempo, as exigências e metas desenvolvidas pelo CNJ e as orientações } \\
\text { provenientes do TCU guiam a instituição num sentido de prestar contas à população e } \\
\text { a outros órgãos públicos de maneira bastante efetiva (Servidor do TRE/RN, 2017). }\end{array}$ \\
\hline \multirow[b]{2}{*}{$\mathrm{JF} / \mathrm{RN}$} & $\begin{array}{l}\text { No que se refere à accountability, destacam-se a boa gestão do orçamento, (...) bem } \\
\text { como a criação de páginas setoriais das unidades jurisdicionais que compõe a JFRN. } \\
\text { O DJE e o Portal da Transparência também se transformaram em importantes } \\
\text { ferramentas (...) (Servidor da JFRN, 2017). }\end{array}$ \\
\hline & $\begin{array}{l}\text { No que se refere à accountability, acredito que o grande destaque da Justiça Federal, } \\
\text { (...), encontra-se na transparência (...), tanto em relação à disponibilidade de } \\
\text { informações em relação aos números de processos julgados e índices afins, quanto à } \\
\text { aplicação de recursos públicos (Servidor da JFRN, 2017). }\end{array}$ \\
\hline \multirow[b]{2}{*}{ TRT/21 } & $\begin{array}{l}\text { A existência de uma supervisão dos trabalhos dos magistrados pela Corregedoria, bem } \\
\text { como canais de acesso à informação reclamação e/ou recebimento de denúncias } \\
\text { (Ouvidoria) (...) (Servidor do TRT/21, 2017). }\end{array}$ \\
\hline & $\begin{array}{l}\text { De toda forma, alguns aspectos da governança, em especial a acessibilidade aos } \\
\text { serviços, o "accountability" e o desempenho apresentam um nível de } \\
\text { desenvolvimento mais acentuado, o que, inclusive, é uma característica da Justiça do } \\
\text { Trabalho como o todo. (Servidor do TRT/21, 2017). }\end{array}$ \\
\hline
\end{tabular}

Fonte: Elaboração pelos autores, 2018.

Um dos fatores de destaque no aspecto do ambiente institucional foi a necessidade de ampliação da interlocução do Judiciário com a sociedade e dos tribunais entre si, a fim de ampliar o diálogo e favorecer a superação de obstáculos para o acesso à Justiça e, consequentemente, para a construção da governança Judicial. A inovação, 
por sua vez, poderá se configurar como uma das importantes ferramentas para facilitar a interação entre a sociedade e o Judiciário. Nesse sentido, destacou um dos participantes:

Sem dúvida que o desempenho como um todo pode ser melhorado, através da busca pela inovação, novos conhecimentos e a procura constante para a melhoria da eficácia e efetividade. Um exemplo a ocorrer é a adoção futura do processo judicial eletrônico (ainda não ativo para o primeiro grau de jurisdição no Rio Grande do Norte, para ilustrar), facilitando a busca das informações processuais pela sociedade e pelas partes. (...) Em busca dessa melhor governança, a Justiça Eleitoral também pode tentar empreender campanhas externas visando o esclarecimento público do real sentido do exercício da cidadania, assim como deve tentar abrir portas para que a população alcance os seus serviços cada vez mais facilmente (SERVIDOR DO TRE/RN, 2017).

No que tange à gestão, somente os participantes do TRT/21 indicaram a necessidade de que o tribunal passe a investir em práticas orientadas por objetivos, metas e indicadores e na capacitação de servidores e magistrados em gestão. Este, por sua vez, é um resultado das mudanças introduzidas no Judiciário brasileiro a partir das estratégias e orientações do Conselho Nacional de Justiça (CNJ). Na pesquisa realizada por Akutsu e Guimarães (2015, p. 954), “os entrevistados destacaram, em especial, as inovações na gestão dos tribunais relacionadas a metas de quantidade de processos julgados e de outras metas de resultados", as quais foram incorporadas ao cotidiano dos tribunais, a partir de orientações provenientes do CNJ.

\section{Considerações finais}

O presente estudo utilizou-se do modelo teórico-metodológico elaborado por Akutsu e Guimarães (2015) a partir de dados empíricos, a fim de investigar a governança judicial a partir de pesquisa realizada na Justiça Federal, no Tribunal Regional Eleitoral e no Tribunal Regional do Trabalho no Rio Grande do Norte.

Concluiu-se que os tribunais pesquisados ainda enfrentam desafios diversos no que tange à construção da governança. Os aspectos mais frequentes foram o acesso à justiça e o ambiente institucional. A despeito do pressuposto de que a estrutura e a disponibilidade de recursos não são obstáculos a serem vencidos pelo Poder Judiciário para a efetiva prestação jurisdicional, foi possível constatar desafios relacionados ao intercâmbio de informações entre tribunais, à adoção pelos tribunais de gestão orientada por objetivos, metas e indicadores, à necessidade de capacitação em gestão e à padronização de informações em tribunais. 
A fim de buscar soluções efetivas para tais questões, o Conselho Nacional de Justiça vem instituindo metas que contribuem com o avanço da governança. Contudo, ainda restam desafios à construção da governança, os quais poderão também contar com a contribuição do CNJ, enquanto instituição que possui como missão o desenvolvimento de políticas judiciárias que promovam a efetividade e a unidade do Poder Judiciário.

A unidade é justamente o objetivo a ser buscado para enfrentar desafios aqui destacados como a diversidade entre culturas organizacionais e a baixa interlocução entre os órgãos do Poder Judiciário. E ainda, deve-se destacar a premente necessidade de que seja estabelecida uma nova relação com a sociedade, buscando-se compreender e minorar a dificuldade de acesso do jurisdicionado e tornar mais próxima a interlocução com agentes diversos.

Por fim, o estudo buscou contribuir, a partir da adequação do modelo teóricometodológico elaborado por Akutsu e Guimarães (2015), com a criação de um modelo de avaliação a ser aplicado nos órgãos do Poder Judiciário, o qual poderá ser ampliado no que tange ao número de participantes, bem como em relação à escuta dos demais agentes que interagem com o Judiciário diariamente - advogados, partes, defensores públicos, membros do Ministério Público.

\section{Referências}

AKuTsu, Luiz; Guimaraes, Tomás de Aquino. Dimensões da governança judicial e sua aplicação ao sistema judicial brasileiro. Rev. direito $G V$, São Paulo, v. 8, n. 1, p. 183-202, junho 2012. Available from <http://www.scielo.br/scielo.php?script=sci_artt ext\&pid=S1808$24322012000100008 \& \operatorname{lng}=$ en $\& n r m=$ iso $>$. Acesso em: 23 Jan. 2020.

\footnotetext{
Governança judicial: proposta de $\overline{\text { modelo }}$ teórico-metodológico. Rev. Adm. Pública - Rio de Janeiro, v.49, n. 4, p. 937958, jul./ago. 2015.

DINIZ, Eli. Governabilidade, democracia $e$ reforma do Estado: os desafios da construção de uma nova ordem no Brasil. In: DINIZ, E.; AzEVEDO, S. (orgs.). Reforma do Estado e democracia no Brasil. Brasília, Editora Universidade de Brasília. 1997.
}

GERALDO, Pedro Barros; FONTAINHA, Fernando; Veronese, Alexandre. Sociologia empírica do direito: Uma introdução. Revista Ética e Filosofia Política - no 12 - Volume 2 Julho de 2010. Disponível em: http://www.ufjf.br/eticaefilosofia/files/2010/06/ 12 2 pedroheitor1.pdf. Acesso em: 10 mar. 2018 .

KISSLER, Leo; HeIDEMANN, Francisco G. Governança pública: novo modelo regulatório para as relações entre Estado, mercado $\mathrm{e}$ sociedade? RAP. Rio de Janeiro, v. 40, n. 3, p. 479-99, Maio/Jun. 2006.

Milani, Carlos; Solinís, Germán. Pensar a democracia na governança mundial: algumas pistas para o futuro. In: MILANI, C.; ARTURI, C.; SolinIS, G. (Orgs). Democracia e Governança Mundial: que regulações para o século XXI? Porto Alegre: UFRGS, Unesco, 2002.

PIRES, Roberto Rocha Coelho; GoMIDE, Alexandre de Ávila. Governança e capacidades estatais: uma análise comparativa de programas 
federais. Rev. Sociol. Polit., v. 24, n. 58, p. 121143, jun. 2016.

REIS, F. W. Governabilidade e instituições políticas. In: Velloso, J. P. dos R. (org.). Governabilidade, sistema político e violência urbana. São Paulo, José Olímpio, 1994.

SECCHI, Leonardo. Modelos organizacionais e reformas da administração pública. $R A P$ - Rio de Janeiro, v. 43, n. 2, p. 347-69, mar./abr. 2009.

Tribunal DE CONTAS DA União. Governança Pública: referencial básico de governança aplicável a órgãos e entidades da administração pública e ações indutoras de melhoria / Tribunal de Contas da União. - Brasília: TCU, Secretaria de Planejamento, Governança e Gestão, 2014. p.96.

\section{Raquel Maria da Costa Silveira}

https://orcid.org/0000-0003-4560-1451

Doutora em Ciências Sociais (UFRN). Mestre em Estudos Urbanos e Regionais (UFRN). Bacharel em Gestão de Políticas Públicas pela Universidade Federal do Rio Grande do Norte (2013). Bacharel em Direito pelo Centro Universitário do Rio Grande do Norte (2013). Docente da UFRN - Departamento de Políticas Públicas.

E-mail: raquelmcsilveira@gmail.com

\section{Maria do Livramento Miranda Clementino}

http://orcid.org/0000-0001-7972-4869

Pós-doutora pela Université Lumiére, Lyon. Doutora em economia pela Universidade Estadual de Campinas (Unicamp). Socióloga e Economista pela Universidade Federal do Rio Grande do Norte (UFRN). Professora Titular do Departamento de Políticas Públicas da Universidade Federal do Rio Grande do Norte (UFRN). Bolsista de Produtividade em Pesquisa do CNPq.

E-mail: mlmclementino@gmail.com

\section{Lindijane de Souza Bento Almeida}

\section{iD https://orcid.org/0000-0002-8520-3530}

Doutora e mestre em Ciências Sociais pela Universidade Federal do Rio Grande do Norte (UFRN), na área de concentração Desenvolvimento Regional. Bacharel em Ciências Sociais (1998), com habilitação em Sociologia e Ciência Política, pela Universidade Federal do Rio Grande do Norte (UFRN). Professora Associada II do Departamento de Políticas Públicas da Universidade Federal do Rio Grande do Norte (UFRN).

E-mail: almeida.lindijane@gmail.com 


\section{APÊNDICE}

\section{QUESTIONÁRIO: PRÁTICAS DE GOVERNANÇA NO JUDICIÁRIO}

O participante deve atribuir valores de 1 a 5 em todos os itens (sendo 1 o valor menos favorável e 5 o mais favorável para cada assertiva).

\section{Quanto à acessibilidade à justiça}

( ) Distância do tribunal ao local de residência do cidadão

( ) Quantidade de Juízes por habitante

( ) Incentivo a práticas de solução extrajudicial de conflitos

( ) Negociação, mediação, conciliação e arbítrio

( ) Oferta de serviços judiciais com rituais simplificados

( ) Renda do cidadão influencia na busca pelo Poder Judiciário

( ) O autor da ação tem garantia de que não será ameaçado pelo réu

( ) Os litigantes têm acesso a bons advogados

( ) A população de baixa renda tem acesso a núcleos de prática jurídica

Total de pontos ( )

\section{Quanto à accountability}

( ) Previsibilidade de decisão dos magistrados em decorrência de histórico jurisprudencial

( ) Supervisão da conduta de magistrados pela corregedoria

( ) Responsabilização de magistrados e servidores pela gestão de recursos públicos

( ) Disponibilidade de informação à população sobre processos em andamento e sobre o funcionamento das varas judiciais

( ) Possibilidade de petição e de consulta aos atos processuais por meios eletrônicos

( ) Coerência na fundamentação dos atos judiciais com o argumento das partes e com as provas juntadas aos autos

( ) Grau de transparência do atos administrativos

( ) Grau de publicidade dos resultados alcançados relativos a quantidade de processos julgados.

Total de pontos $(\quad)$

\section{Quanto à independência do Judiciário}

( ) Possibilidade do Executivo impor restrições orçamentárias ao Judiciário

( ) Salários adequados de magistrados e servidores

( ) Adoção de regras de impessoalidade para nomeação de magistrados de $2^{\circ}$ grau e tribunais superiores

( ) Garantia constitucional de vitaliciedade dos mandatários

( ) Repercussão na imprensa dos julgados tidos como mais importantes

( ) Eficácia da proteção aos magistrados que sofrem ameaças por resultados de julgamento

( ) Critérios de promoção nos tribunais 
Total de pontos $(\quad)$

\section{Quanto a recursos e estrutura}

( ) Rotatividade de magistrados nas respectivas varas judicias

( ) Confiabilidade, robustez e qualidade de sistemas de informação

( ) Adequação das práticas de incentivo às carreiras de magistrados e servidores

( ) Possibilidade de intercâmbio de informações entre tribunais via sistema de informações judiciais

( ) Existência de instalações e equipamentos adequados para o atendimento ao público

( ) Grau de adoção pelos tribunais de gestão orientada por objetivos, metas e indicadores de desempenho

( ) Conhecimento, experiência e capacitação dos magistrados para julgar processos sob sua jurisdição

( ) Adequação de estruturas funcionais nos organogramas dos tribunais à gestão dos processos judiciais

( ) Conhecimento, experiência e capacitação de servidores e magistrados em gestão

( ) Nível de adoção de padronização de informações em tribunais

Total de pontos ( )

\section{Quanto ao desempenho}

( ) Impessoalidade das decisões judiciais

( ) Tempo de julgamento

( ) Custo do processo judicial para as partes litigantes

( ) Estoque de processos não julgados

( ) Ações repetidas julgadas com base nas orientações decorrentes de julgamento de ações de repercussão geral

( ) Percentual de ações coletivas relevantes julgadas em relação a ações individuais

( ) Percentual de cumprimento de metas do tribunal

Total de pontos ( )

\section{Quanto ao ambiente institucional}

( ) Possibilidades oferecidas pela legislação processual para interposição de recursos de caráter protelatório

( ) Complexidade do jargão jurídico, da legislação e dos procedimentos judiciais

( ) Disponibilidade de delegados e defensores públicos do Ministério Público atuante, para atender à população de baixa renda

( ) Percentual de litígios decorrente do inconformismo dos cidadãos com ações da própria administração pública

( ) Adoção de inovações para melhorar a estrutura de funcionamento do Poder Judiciário

( ) Existência de indicadores de acompanhamento quanto à eficiência dos tribunais

( ) Grau de discussão dos objetivos estratégicos pala alta administração dos tribunais com setores representativos da sociedade

( ) Frequência de campanhas educativas 
( ) E disponibilidade de informações aos cidadãos acerca de seus direitos perante o Poder Judiciário

( ) Frequência de campanhas sobre justiça itinerante e justiça comunitária

( ) Grau de diversidade entre culturas organizacionais nos órgãos do Poder Judiciário

( ) Grau de interlocução entre os órgãos do Poder Judiciário

Total de pontos

Questionamento aos participantes: O seu órgão realiza práticas de boa governança? 